\title{
Fatty Acid Profile in Erythrocyte Membranes and Plasma Phospholipids Affects Significantly the Extent of Inflammatory Response to Coronary Stent Implantation
}

\author{
T. ČERMÁK ${ }^{1}$, V. MUŽÁKOVÁ ${ }^{1}$, J. MATĚJKA ${ }^{2}$, J. SKALICKÝ ${ }^{3}$, P. LAŠTOVIČKA ${ }^{1}$, \\ M. LÍBALOVÁ ${ }^{1}$, R. KANĎÁR ${ }^{1}$, V. NOVOTNÝ ${ }^{2}$, A. ČEGAN ${ }^{1}$ \\ ${ }^{1}$ Department of Biological and Biochemical Sciences, Faculty of Chemical Technology, University \\ of Pardubice, Pardubice, Czech Republic, ${ }^{2}$ Department of Cardiology, Regional Hospital of \\ Pardubice, Pardubice, Czech Republic, ${ }^{3}$ Department of Clinical Biochemistry and Diagnostics, \\ Regional Hospital of Pardubice, Pardubice, Czech Republic
}

Received September 18, 2015

Accepted April 15, 2016

On-line August 19, 2016

\section{Summary}

In coronary heart disease, the treatment of significant stenosis by percutaneous coronary intervention (PCI) with stent implantation elicits local and systemic inflammatory responses. This study was aimed at evaluation of the dynamics of inflammatory response and elucidation of the relationship between the fatty acid profile of red blood cell (RBC) membranes or plasma phospholipids and inflammation after PCI. Highsensitivity C-reactive protein (hsCRP), interleukin-6 (IL-6), serum amyloid A (SAA), malondialdehyde (MDA) and the fatty acid profiles were determined in patients with advanced coronary artery disease undergoing PCI before, $24 \mathrm{~h}$ and $48 \mathrm{~h}$ after drugeluting stent implantation $(n=36)$. Patients after PCI exhibited a significant increase in studied markers (hSCRP, IL-6, SAA, MDA). Many significant associations were found between the increase of IL-6, resp. SAA and the amounts of n-6 polyunsaturated fatty acids (namely linoleic, dihomo- $\gamma-$ linolenic, docosatetraenoic and docosapentaenoic acid), resp. saturated fatty acids (pentadecanoic, stearic, nonadecanoic) in erythrocyte membranes. The magnitude of the inflammatory response to $\mathrm{PCI}$ is related to erythrocyte membrane fatty acid profile, which seems to be a better potential predictor of elevation of inflammatory markers after PCI than plasma phospholipids.

\section{Key words}

Lipids • Coronary artery disease • Inflammation • Fatty acids • Coronary restenosis

\section{Corresponding author}

V. Mužáková, Department of Biological and Biochemical Sciences, Faculty of Chemical Technology, University of Pardubice, Studentská 573, 53210 Pardubice, Czech Republic. Fax: +420 466037 068. E-mail: Vladimira.Muzakova@upce.cz

\section{Introduction}

Atherosclerosis and diseases of the cardiovascular system belong to the most common causes of death in Central Europe. Percutaneous coronary intervention (PCI) is an invasive procedure resulting in the recovery of vascular patency in patients with coronary atherosclerosis. However, PCI induces an inflammatory reaction that plays a crucial role in the pathogenesis of neointimal proliferation, which is the main cause of stent restenosis (Kornowski et al. 1998, Liuzzo et al. 1998, Buffon et al. 1999). Interleukin 6 (IL-6) concentration increases after PCI, and the magnitude of its elevation correlates with the occurrence of late restenosis (Ikeda et al. 2001). Similarly, the associations between high sensitive C-reactive protein (hsCRP) or serum amyloid A (SAA) and restenosis were found (Liuzzo et al. 1994, Schillinger et al. 2002).

Recently, the association of inflammation with the fatty acid contents was reported (Fernandez-Real et al. 2003, Calder 2012, Rangel-Huerta et al. 2012). The 
n-3 and n-6 polyunsaturated fatty acids (PUFA) are precursors of eicosanoids that significantly affect the inflammatory reaction. The n-3 PUFA, particularly eicosapentaenoic and docosahexaenoic acid, compete with n-6 PUFA for enzymes in the biosynthetic pathway of eicosanoids. Ratio of n-3 and n-6 PUFA influences hemodynamics, vascular tone and inflammation (Hirafuji et al. 2003). Some epidemiological studies have found that levels of n-3 PUFA in plasma, as well as in erythrocyte membranes, negatively correlate with plasma proinflammatory markers, including CRP and IL-6 in patients with stable coronary artery disease (Ferrucci et al. 2006, Farzaneh et al. 2009). It was suggested that the successful replacement of n-6 PUFA with n-3 PUFA in cell membranes could result in a decrease of cellular responses to mitogenic and inflammatory stimuli (Bagga et al. 2003).

Monounsaturated fatty acids (MUFA) with the cis-configuration are mostly anti-atherogenic, antithrombogenic and resistant to lipoperoxidation. MUFA decrease serum low density lipoproteins (LDL) and positively influence formation of high density lipoproteins (HDL). LDL, rich in monounsaturated fatty acids, are less taken up by macrophages and the risk of lipid peroxidation is therefore reduced (Moreno et al. 2008).

Several studies described the effect of n-3 PUFA supplementation on inflammation and restenosis after PCI, but the influence of a whole spectrum of fatty acids should be taken into account. Relations in all groups of fatty acids need to be studied in more details to understand the mechanism of their association with inflammation after PCI. We have focused on evaluation of the role of individual fatty acids in erythrocyte membranes and plasma phospholipids (PL) in the inflammatory response to coronary stent implantation in patients with acute coronary syndrome. Inflammatory response is highly individual and this reaction could be affected by plasma fatty acid composition and composition of fatty acids in cell membranes, what is reflected by the erythrocyte membrane fatty acid profile before stenting. However, analyses of the fatty acid composition of these lipids are usually not available for routine laboratories. The aim of this study is to evaluate the relationship between not only PUFA, but the whole spectrum of fatty acids, and inflammatory response as well as oxidative stress progression after PCI.

\section{Materials and Methods}

\section{Subjects}

This cross-sectional study involved 36 patients diagnosed with significant coronary atherosclerosis undergoing PCI. The study did not include patients with serious health complications, ST Segment Elevation Myocardial Infarction (STEMI), heart failure according to New York Heart Association (NYHA) II-IV, renal failure, thyroid dysfunction, hepatic or oncology disease or patients that regularly consume alcohol (based on the questionnaire). Group characteristics are given in Table 1. The appropriate institutional approval of the review board has been obtained as well as the principles outlined in the Declaration of Helsinki for all human or animal experimental investigations have been followed. Written informed consent was obtained from all the participants. The study was approved by the Ethical Committee on Human Research of the Regional Hospital of Pardubice (No 434/13.12.2013). All interventions were performed with a standard technique, and all patients received drug-eluting stents (Everolimus). Before intervention, all patients received weight-adjusted intravenous heparin with a target activated clotting time of 250-350 s.

Table 1. Characteristics of the study sample of patients $(n=36)$.

\begin{tabular}{|c|c|}
\hline Women (n) & 10 \\
\hline $\operatorname{Men}(n)$ & 26 \\
\hline Age $^{*}$ (years) & $67(14)$ \\
\hline Hypertension (n) & 25 \\
\hline Diabetes mellitus (n) & 12 \\
\hline$B M I^{*}\left(\mathrm{~kg} / \mathrm{m}^{2}\right)$ & $28.1(6.5)$ \\
\hline$h s C R P^{*}(\mathrm{mg} / \mathrm{l})$ & $3.18(2.11)$ \\
\hline$I L-6^{*}(n g / l)$ & $1.61(3.87)$ \\
\hline$S A A^{*}(m g / l)$ & $6.01(4.72)$ \\
\hline$M D A *(\mu \mathrm{mol} / l)$ & $1.25(0.41)$ \\
\hline$H D L-C^{*}(\mathrm{mmol} / \mathrm{l})$ & $1(0.39)$ \\
\hline$L D L-C^{*}(\mathrm{mmol} / \mathrm{l})$ & $2.13(1.19)$ \\
\hline Total-C* (mmol/l) & $3.60(1.57)$ \\
\hline$P-T G^{*}(\mathrm{mmol} / \mathrm{l})$ & $1.17(0.63)$ \\
\hline Albumin* $(g / l)$ & $35.50(3)$ \\
\hline
\end{tabular}

BMI - body mass index, hsCRP - high sensitive C-reactive protein, IL-6 - interleukin 6, SAA - serum amyloid A, MDA malondialdehyde, HDL-C - HDL cholesterol, LDL-C - LDL cholesterol, Total-C - total cholesterol, P-TG - plasma triglyceride. * median (IQR - interquartile range). 


\section{Whole blood sample collection}

Venous blood samples $(9 \mathrm{ml})$ were collected in tubes with EDTA (The Vacuette Detection Tube, No. 455036, Greiner Bio-One GmbH, Kremsmünster, Austria) before, 24 and $48 \mathrm{~h}$ after PCI. Blood was immediately centrifuged at $1500 \times \mathrm{g}$ for $20 \mathrm{~min}$ and aliquots of plasma and buffy coat were separated into cryotubes. One $\mathrm{ml}$ of erythrocytes was taken from the center of the erythrocyte column and immediately stored at $-80{ }^{\circ} \mathrm{C}$.

\section{Determination of inflammatory markers}

HsCRP, IL-6 and SAA were measured in the Regional Hospital of Pardubice. HsCRP was determined by the standard procedure using the analytical system VISTA $^{\circledR}$; IL-6 with an Immulite ${ }^{\circledR}$ immunochemistry analyzer and SAA with a BN ProSpec ${ }^{\circledR}$ laser nephelometer (all provided by Siemens Healthcare
Diagnostics Inc., USA).

\section{Determination of malondialdehyde (MDA)}

The analysis of MDA was performed as previously described (Kand'ár et al. 2002). Briefly, plasma MDA was quantified after its conversion to the malondialdehyde-thiobarbituric acid (TBA) complex which was accomplished using an isocratic elution on a LiChroCart 250 × 4 mm, Purospher Star RP-18e, $5 \mu \mathrm{m}$, analytical column fitted with a LiChroCart $4 \times 4 \mathrm{~mm}$, Purospher Star RP-18e, $5 \mu \mathrm{m}$, guard column (Merck, Darmstadt, Germany). Mixture of $35 \%$ methanol in $8.3 \mathrm{mM}$ phosphate buffer, $\mathrm{pH} 7.2$, was used as the mobile phase for determining the $\operatorname{MDA}(\mathrm{TBA})_{2}$ derivative. The flow rate was kept constant at $0.7 \mathrm{ml} / \mathrm{min}$. The separation ran at $37^{\circ} \mathrm{C}$. Effluent was monitored with UV/Vis detector at $532 \mathrm{~nm}$.

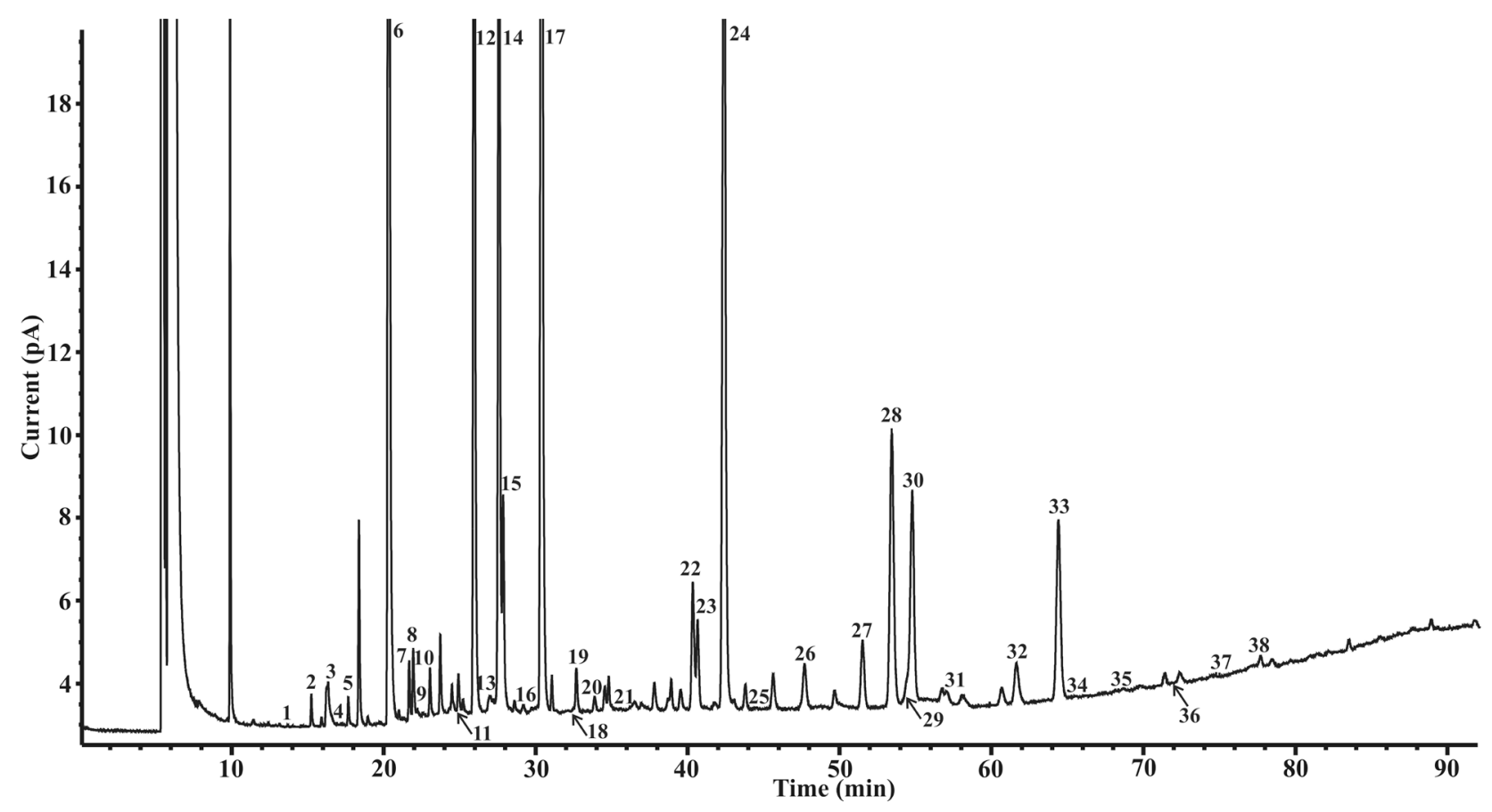

Fig. 1. Representative chromatogram of fatty acid profile of plasma sample. Peaks: 1. 12-methyltridecanoic acid, 2. myristic acid, 3. 13-methyltetradecanoic acid, 4. 12-methyltetradecanoic acid, 5. pentadecanoic acid, 6. palmitic acid, 7. sapienic acid, 8. cis-palmitoleic acid, 9. 14-methylhexadecanoic acid, 10. heptadecanoic acid, 11. 16-methylheptadecanoic acid, 12. stearic acid, 13. trans-vaccenic acid, 14. oleic acid, 15. cis-vaccenic acid, 16. nonadecanoic acid, 17. linoleic acid, 18. $y$-linolenic acid, 19. arachidic acid, 20. a-linolenic acid, 21. stearidonic acid, 22. dihomo-y-linolenic acid, 23. behenic acid, 24. arachidonic acid, 25. eicosatetraenoic acid (n-3), 26. eicosapentaenoic acid (n-3), 27. lignoceric acid, 28. cis-13,16,19-docosatrienoic acid INTERNAL STANDARD, 29. docosatetraenoic acid $(n-6)$, 30. nervonic acid, 31. docosapentaenoic acid $(n-6)$, 32. docosapentaenoic acid (n-3), 33. docosahexaenoic acid (n-3), 34. cerotic acid, 35. tetracosatetraenoic acid $(n-6)$, 36. tetracosapentaenoic acid (n-6), 37. tetracosapentaenoic acid (n-3), 38. tetracosahexaenoic acid (n-3). GC conditions: temperature of injector was $250{ }^{\circ} \mathrm{C}$ and FID $280^{\circ} \mathrm{C}$; inject volume was $1 \mu \mathrm{l}$ (split ratio $10: 1$ ); the flow rate of helium was $3 \mathrm{ml} / \mathrm{min}$; stationary phase was the capillary column HP-88 (100 m in length, $250 \mu \mathrm{m}$ i.d, $0.25 \mu \mathrm{m}$ in film thickness). The initial temperature was $130^{\circ} \mathrm{C}$ for $1 \mathrm{~min}$. The temperature gradient was as follows: $2^{\circ} \mathrm{C} / \mathrm{min}$ up to $176^{\circ} \mathrm{C}$, maintained for $2 \mathrm{~min} ; 1^{\circ} \mathrm{C} / \mathrm{min}$ to $186^{\circ} \mathrm{C}$, maintained for $1 \mathrm{~min} ; 0.2^{\circ} \mathrm{C} / \mathrm{min}$ to $190^{\circ} \mathrm{C}$, maintained for $1 \mathrm{~min} ; 1^{\circ} \mathrm{C} / \mathrm{min}$ to $220^{\circ} \mathrm{C}$, maintained for $4 \mathrm{~min}$. 
Determination of erythrocyte membrane fatty acid profile Defrosted erythrocytes $(200 \mu \mathrm{l})$ were mixed thoroughly (by vortex) with $1800 \mu$ l of distilled water. After thawing and mixing, the samples were centrifuged for $10 \mathrm{~min}$ at $12050 \times \mathrm{g}$. The sediment was washed three times with $1600 \mu \mathrm{l}$ of distilled water with subsequent centrifugation. $1700 \mu \mathrm{l}$ of the supernatant was collected after the last washing. One $\mathrm{ml}$ of isopropanol/ n-heptane/ortho-phosphoric acid (2 M) (40:20:1, v/v/v) was added to the resulting sediment of erythrocyte membranes. The mixture was mixed by vortex and incubated for $10 \mathrm{~min}$ at room temperature. The internal standard (cis-13,16,19-docosatrienoic acid, $10 \mu \mathrm{g} / \mathrm{ml}$, Cayman Chemical, Ann Arbor, MI, USA) in a methanol/toluene $(1: 4, \mathrm{v} / \mathrm{v})(400 \mu \mathrm{l})$ and $300 \mu \mathrm{l}$ distilled water were mixed by vortex and centrifuged for 5 minutes at $2910 \times \mathrm{g}$. The upper organic layer was transferred to a Pyrex test tube and evaporated to dryness under nitrogen (Linde Gas a. s., Prague, Czech Republic). Two $\mathrm{ml}$ methanol/toluene mixture $(1: 4, \mathrm{v} / \mathrm{v})$ were added to the sample in the Pyrex test tube. $200 \mu$ of acetyl chloride was added to the sample in a thermal block. The mixture was heated for $1 \mathrm{~h}$ at $100{ }^{\circ} \mathrm{C}$ in a closed Pyrex test tube, cooled and neutralized with $5 \mathrm{ml}$ of $6 \% \mathrm{~K}_{2} \mathrm{CO}_{3}$. Finally, the solution was mixed for $2 \mathrm{~min}$ and then centrifuged for $10 \mathrm{~min}$. The organic phase was transferred to a new test tube and evaporated to a volume of $100 \mu \mathrm{l}$ under a nitrogen atmosphere (Peter et al. 2009).

The samples were analyzed by gas chromatography. An Agilent 7890 gas chromatograph was used for determination of the fatty acid profile. The injector temperature was $250{ }^{\circ} \mathrm{C}$ and the FID detector temperature $280^{\circ} \mathrm{C}$. The temperature program was set as follows: $130{ }^{\circ} \mathrm{C}$ for $1 \mathrm{~min} ; 2^{\circ} \mathrm{C} / \mathrm{min}$ up to $176^{\circ} \mathrm{C}$, maintained for $2 \mathrm{~min} ; 1^{\circ} \mathrm{C} / \mathrm{min}$ to $186^{\circ} \mathrm{C}$, maintained for $1 \mathrm{~min} ; 0.2^{\circ} \mathrm{C} / \mathrm{min}$ to $190^{\circ} \mathrm{C}$, maintained for $1 \mathrm{~min}$; $1{ }^{\circ} \mathrm{C} / \mathrm{min}$ to $220^{\circ} \mathrm{C}$, maintained for $4 \mathrm{~min}$. The results were obtained after final processing of the peak areas and are reported as a percentage of the total fatty acids. Cis-13,16,19-docosatrienoic acid was used as an internal standard. The example of chromatogram with 38 measured fatty acids including internal standard is shown in Figure 1.

\section{Statistical analysis}

Descriptive statistics (median, first and third quartile, mean, standard deviation) and all statistical analyses were computed using STATISTICA 12 (StatSoft CR, s.r.o., Czech Republic) and Sigmastat version 3.5
(Systat Software Inc., Point Richmond, CA, USA). Analysis of variance (ANOVA) was performed to investigate dynamic changes in levels of inflammatory markers and MDA as a function of sex, age and diabetes. The Wilcoxon test was used to compare the values of inflammatory markers and MDA before, $24 \mathrm{~h}$ and $48 \mathrm{~h}$ after PCI. Relationships between the content of erythrocytes and plasma fatty acids, inflammatory and oxidative stress markers were expressed as nonparametric Spearman's correlations. $\quad \mathrm{P} \leq 0.05$ was considered statistically significant.

Table 2. Dynamics of inflammation markers and MDA, marker of lipoperoxidation, as a function of gender, age and diabetes.

\begin{tabular}{|c|c|c|c|c|}
\hline & Factor & $\mathbf{F}$ & $\mathbf{p}$ & $\begin{array}{c}\text { Power } \\
(1-\beta)\end{array}$ \\
\hline$\triangle h s C R P$ & Sex & 0.074 & 0.788 & 0.050 \\
\hline \multirow[t]{2}{*}{$24 h$} & Age & 0.081 & 0.923 & 0.050 \\
\hline & Diabetes & 1.741 & 0.197 & 0.124 \\
\hline$\triangle h s C R P$ & Sex & 1.164 & 0.289 & 0.064 \\
\hline \multirow[t]{2}{*}{$48 h$} & Age & 2.314 & 0.116 & 0.252 \\
\hline & Diabetes & 0.016 & 0.901 & 0.050 \\
\hline$\Delta I L-6$ & Sex & 0.374 & 0.545 & 0.050 \\
\hline \multirow[t]{2}{*}{$24 h$} & Age & 1.026 & 0.371 & 0.052 \\
\hline & Diabetes & 0.383 & 0.541 & 0.050 \\
\hline$\Delta I L-6$ & Sex & 1.104 & 0.302 & 0.058 \\
\hline \multirow[t]{2}{*}{$48 h$} & Age & 1.502 & 0.240 & 0.120 \\
\hline & Diabetes & 2.418 & 0.131 & 0.197 \\
\hline$\triangle S A A$ & Sex & 0.106 & 0.747 & 0.050 \\
\hline \multirow[t]{2}{*}{$24 h$} & Age & 0.152 & 0.860 & 0.050 \\
\hline & Diabetes & 0.846 & 0.365 & 0.050 \\
\hline$\triangle S A A$ & Sex & 2.133 & 0.155 & 0.166 \\
\hline \multirow[t]{2}{*}{$48 h$} & Age & 2.998 & 0.066 & 0.367 \\
\hline & Diabetes & 0.187 & 0.668 & 0.050 \\
\hline$\triangle M D A$ & Sex & 0.202 & 0.656 & 0.050 \\
\hline \multirow[t]{2}{*}{$24 h$} & Age & 0.167 & 0.847 & 0.050 \\
\hline & Diabetes & 0.453 & 0.506 & 0.050 \\
\hline$\triangle M D A$ & Sex & 0.722 & 0.402 & 0.050 \\
\hline \multirow[t]{2}{*}{$48 h$} & Age & 0.251 & 0.780 & 0.050 \\
\hline & Diabetes & 0.479 & 0.494 & 0.050 \\
\hline
\end{tabular}

The $\mathrm{F}$ test statistic is provided for comparisons within each factor. The $p$ value is the probability of being wrong in concluding that there is a true difference between the groups. There are significant differences if $p<0.05$. The power or sensitivity is the probability that the test will detect the observed difference among the groups if there really is a difference. The closer the power is to 1 , the more sensitive the test. Traditionally, the power of the performed test should be $>0.8$. Less than desired power indicates you are less likely to detect a difference when one actually exists. HsCRP - high sensitive C-reactive protein, IL-6 - interleukin 6, MDA - malondialdehyde, SAA - serum amyloid A. 


\section{Results}

The group of patients consisted of 26 men and 10 women undergoing PCI with subsequent stent implantation for stable (16) or unstable (20) angina pectoris. Initial levels of inflammatory markers and MDA (marker of lipoperoxidation), BMI and cholesterol concentrations are included in group characteristic in Table 1.

Using ANOVA, no effect of sex, age, occurrence of diabetes on inflammatory markers and MDA content was found (Table 2).

Patients after PCI exhibited a significant increase in inflammatory markers. The earliest responses, with maxima after $24 \mathrm{~h}$, were observed in case of IL-6 and hs-CRP, followed by the elevation of SAA, with maximum after $48 \mathrm{~h}$ (Fig. 2). Also elevation of oxidative stress (estimated via MDA, stable product of lipoperoxidation) reached its maximum after $48 \mathrm{~h}$.

The initial levels of fatty acid groups, namely of saturated fatty acids (SFA), trans-MUFA, cis-MUFA, n-3 PUFA and n-6 PUFA as well as individual fatty acids were correlated with the magnitude of the increase in CRP, IL-6, SAA and MDA concentrations after PCI. Statistically significant correlations are shown in Tables 3 and 4. Survey of all measured fatty acids is given in Table 5. Our data show the close relationship of inflammatory markers with fatty acids in erythrocyte membranes, especially in case of IL-6 and SAA. Spearman positive correlations were found between the magnitude of the increase in IL-6 and total n-6 PUFA. Highly significant correlations were found with each n-6 fatty acids, namely with docosatetraenoic acid, docosapentaenoic acid, linoleic acid and dihomo- $\gamma$ linolenic acid. Positive correlation was found between IL-6 and n6/n3 ratio. Further, we have found close relationship between SAA and erythrocyte membrane SFA, specifically with pentadecanoic acid, stearic acid, nonadecanoic acid and cerotic acid. Contradictory role was found in case of palmitoleic acid in erythrocyte membranes, which significantly contributed to the increase in SAA after PCI, being negatively associated with IL-6.
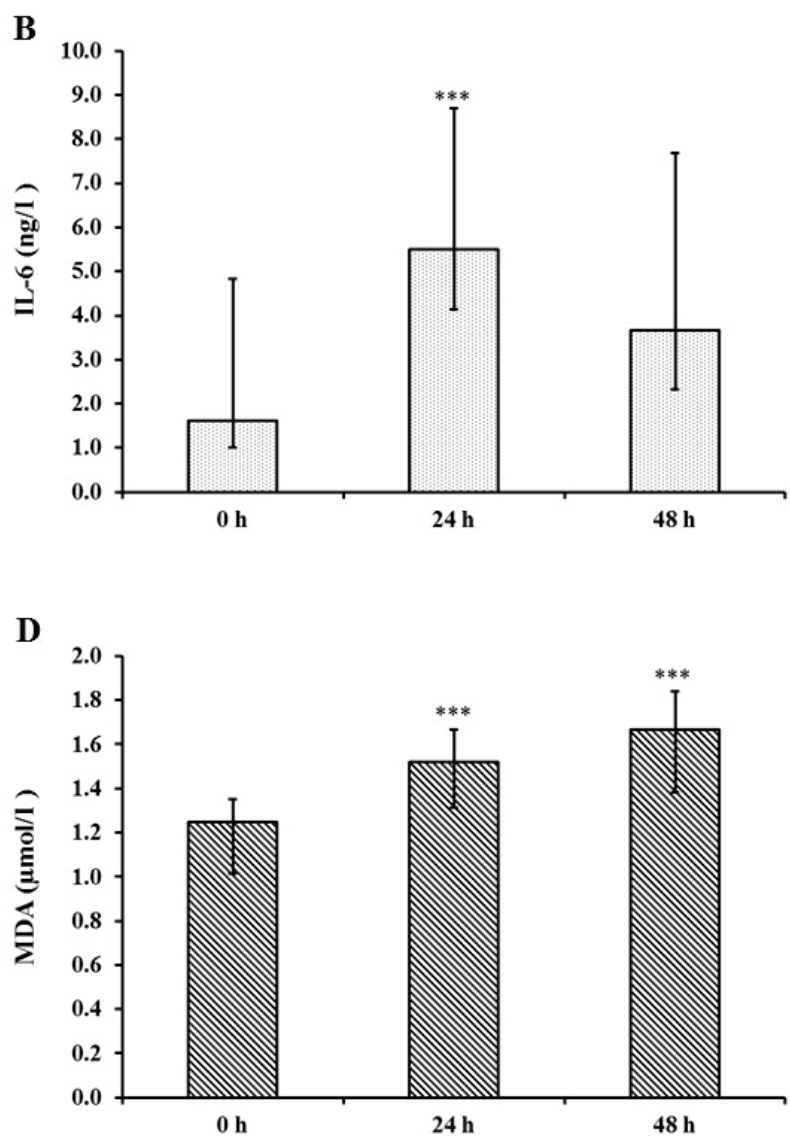

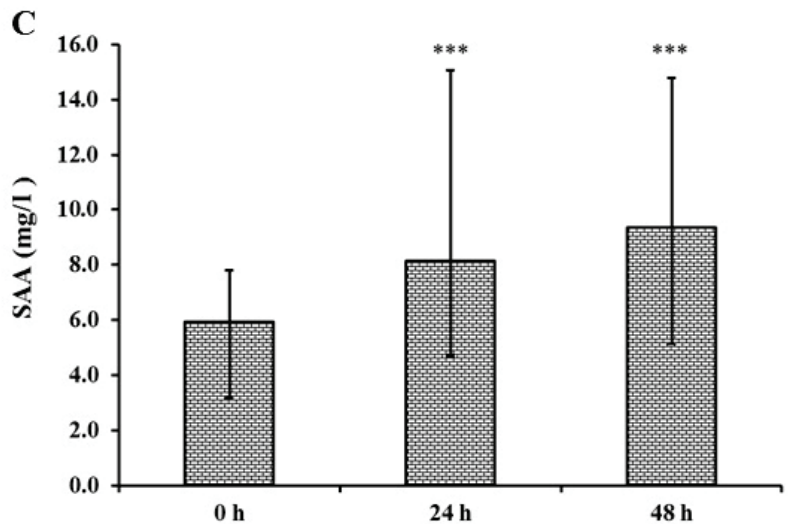

Fig. 2. Dynamics of the inflammatory response and oxidative stress after PCI. (A) Levels of IL-6 during $48 \mathrm{~h}$ after PCI, (B) levels of hsCRP during $48 \mathrm{~h}$ after PCI, (C) SAA levels during $48 \mathrm{~h}$ after PCI, (D) MDA levels during $48 \mathrm{~h}$ after PCI. IL-6 - interleukin-6, PCI - percutaneous transluminal coronary angioplasty, hSCRP - high-sensitivity C-reactive protein, SAA - serum amyloid A, MDA - malondialdehyde. The results are expressed as median and IQR (interquartile range). ${ }^{*} \mathrm{p}<0.05, * * \mathrm{p}<0.01, * * * \mathrm{p}<0.001$. 
Table 3. Statistically significant correlations of erythrocyte fatty acids with inflammatory markers and malondialdehyde.

\begin{tabular}{|c|c|c|c|c|c|c|c|c|c|}
\hline \multirow[t]{2}{*}{ Fatty acids } & \multicolumn{2}{|c|}{$\begin{array}{c}\Delta \text { CRP } 24 \text { h } \\
(\mathrm{mg} / \mathrm{l})\end{array}$} & \multicolumn{2}{|c|}{$\begin{array}{c}\Delta \text { CRP } 48 \text { h } \\
(\mathrm{mg} / \mathrm{l})\end{array}$} & \multirow[t]{2}{*}{ Fatty acids } & \multicolumn{2}{|c|}{$\begin{array}{c}\Delta \text { SAA } 24 \text { h } \\
(\mathrm{mg} / \mathrm{l})\end{array}$} & \multicolumn{2}{|c|}{$\begin{array}{c}\Delta \mathrm{SAA} 48 \mathrm{~h} \\
(\mathrm{mg} / \mathrm{l})\end{array}$} \\
\hline & $\mathbf{r}$ & $\mathbf{p}$ & $\mathbf{r}$ & $\mathbf{p}$ & & $\mathbf{r}$ & $\mathbf{p}$ & $\mathbf{r}$ & $\mathbf{p}$ \\
\hline Pentadecanoic & 0.39 & 0.019 & 0.20 & 0.232 & 12-Methyltridecanoic & 0.46 & 0.005 & 0.27 & 0.123 \\
\hline \multirow[t]{5}{*}{ Nonadecanoic } & 0.33 & 0.048 & 0.17 & 0.332 & Pentadecanoic & 0.40 & 0.015 & 0.21 & 0.223 \\
\hline & \multirow{3}{*}{\multicolumn{2}{|c|}{$\begin{array}{c}\Delta \text { IL-6 } 24 \text { h } \\
(\mathrm{ng} / \mathrm{l})\end{array}$}} & & & Sapienic & 0.34 & 0.046 & 0.05 & 0.766 \\
\hline & & & \multirow{2}{*}{\multicolumn{2}{|c|}{$\begin{array}{c}\Delta \text { IL-6 } 48 \text { h } \\
(\mathrm{ng} / \mathrm{l})\end{array}$}} & cis-Palmitoleic & 0.43 & 0.009 & 0.15 & 0.382 \\
\hline & & & & & Stearic & 0.34 & 0.045 & 0.08 & 0.648 \\
\hline & $\mathbf{r}$ & $\mathbf{p}$ & $\mathbf{r}$ & $\mathbf{p}$ & Nonadecanoic & 0.34 & 0.041 & 0.16 & 0.371 \\
\hline & & & & & Eicosapentaenoic (n3) & 0.06 & 0.717 & 0.37 & 0.032 \\
\hline Myristic & -0.35 & 0.038 & -0.08 & 0.636 & Cerotic & 0.38 & 0.023 & 0.14 & 0.445 \\
\hline 13-Methylmyristic & -0.34 & 0.048 & -0.02 & 0.911 & Total SFA & 0.40 & 0.017 & 0.07 & 0.686 \\
\hline cis-Palmitoleic & -0.37 & 0.030 & -0.11 & 0.534 & & & & & \\
\hline 14-Methylhexanoic & -0.36 & 0.032 & -0.19 & 0.288 & & \multirow{2}{*}{\multicolumn{2}{|c|}{$\begin{array}{c}\Delta \text { MDA } 24 \text { h } \\
(\mu \mathrm{mol} / \mathrm{l})\end{array}$}} & \multirow{2}{*}{\multicolumn{2}{|c|}{$\begin{array}{c}\Delta \text { MDA } 48 \mathrm{~h} \\
(\mu \mathrm{mol} / \mathrm{l})\end{array}$}} \\
\hline trans-Vaccenic & -0.40 & 0.018 & -0.20 & 0.260 & & & & & \\
\hline Linoleic & 0.42 & 0.012 & 0.08 & 0.673 & & $\mathbf{r}$ & $\mathbf{p}$ & $\mathbf{r}$ & p \\
\hline Stearidonic & -0.40 & 0.018 & 0.00 & 0.978 & & & & & \\
\hline Dihomo- $\gamma$-linolenic & 0.46 & 0.005 & 0.09 & 0.611 & 12-Methyltetradecanoic & -0.37 & 0.025 & -0.15 & 0.394 \\
\hline Docosatetraenoic (n6) & 0.38 & 0.024 & 0.03 & 0.872 & cis-Palmitoleic & -0.22 & 0.188 & -0.36 & 0.029 \\
\hline Docosapentaenoic (n6) & 0.34 & 0.048 & -0.04 & 0.806 & 14-Methylhexanoic & -0.34 & 0.044 & -0.33 & 0.050 \\
\hline Docosapentaenoic (n3) & 0.41 & 0.013 & 0.04 & 0.827 & Stearic & -0.27 & 0.116 & -0.38 & 0.024 \\
\hline Total n-6 PUFA & 0.34 & 0.049 & 0.04 & 0.814 & Dihomo- $\gamma$-linolenic & 0.41 & 0.014 & 0.25 & 0.138 \\
\hline$n 6 / n 3$ & 0.41 & 0.014 & 0.08 & 0.670 & Docosapentaenoic (n3) & 0.36 & 0.030 & 0.27 & 0.108 \\
\hline$B C F A$ & -0.37 & 0.029 & -0.20 & 0.250 & Total SFA & -0.32 & 0.054 & -0.35 & 0.036 \\
\hline
\end{tabular}

Relationships between the content of erythrocytes fatty acids, inflammatory markers and oxidative stress were expressed as nonparametric Spearman's correlations. The $r$ value means Spearman's correlation coefficient, $p$ value is the probability of being wrong in concluding that there is a true difference between the groups. There are significant differences if $p \leq 0.05$. HsCRP - high sensitive C-reactive protein, IL- 6 - interleukin 6 , MDA - malondialdehyde, SAA - serum amyloid A, PUFA - polyunsaturated fatty acids, SFA saturated fatty acids, BCFA - branched chain fatty acids.

\section{Discussion}

The dynamics of inflammatory markers IL-6, CRP and SAA were studied during $48 \mathrm{~h}$ after the PCI with subsequent stent implantation. The maximum inflammatory reaction was reached $24 \mathrm{~h}$ and $48 \mathrm{~h}$ after PCI, which is in agreement with previous studies (Inoue et al. 2005, Lasave et al. 2007, Silva et al. 2012). Inoue et al. (2005) indicated that increased levels of CRP after PCI predict an increased risk of in-stent restenosis. The increase in proinflammatory cytokine IL-6 with its maximum $24 \mathrm{~h}$ after the procedure is in agreement with the results of Kochiadakis et al. (2007). Our results suggest that the progression of the inflammatory response is closely associated with the fatty acid profile in red blood cell membranes and plasma phospholipids before PCI. We have found many significant correlations of fatty acids with IL-6. The obtained results proved a positive correlation between IL- 6 and linoleic acid, a precursor of arachidonic acid producing proinflammatory eicosanoids of group 2. It can be assumed that the amount of arachidonic acid in inflammatory cells may also be influenced by the dietary intake of its precursor, linoleic acid (Yaqoob et al. 2000). A strong positive correlation was reported between the amount of arachidonic acid in inflammatory cells and the ability of those cells to produce eicosanoids (Peterson et al. 1998). Arachidonic acid is usually the major substrate for eicosanoid synthesis but we did not find any statistically significant correlation between this fatty acid and the increase in inflammation. There is a possibility that arachidonic acid was quickly metabolized to eicosanoids, immediately after its formation from linoleic acid.

An increased intake of $\gamma$-linolenic acid or 
dihomo- $\gamma$-linolenic acid is supposed to have antithrombogenic and anti-inflammatory effects (Kernoff et al. 1977, Johnson et al. 1997). In our study, however, content of these n-6 PUFA, especially of DGLA in erythrocyte membranes before PCI significantly positively correlated with increased IL-6 after intervention.

Table 4. Statistically significant correlations of phospholipid fatty acids (\%) with inflammatory markers and malondialdehyde.

\begin{tabular}{|c|c|c|c|c|}
\hline & \multicolumn{2}{|c|}{$\begin{array}{c}\Delta \text { CRP } 24 \text { h } \\
(\mathrm{mg} / \mathrm{l})\end{array}$} & \multicolumn{2}{|c|}{$\underset{(\mathrm{mg} / \mathrm{l})}{\Delta \mathrm{CRP} 48 \mathrm{~h}}$} \\
\hline & $\mathbf{r}$ & $\mathbf{p}$ & $\mathbf{r}$ & $\mathbf{p}$ \\
\hline Myristic & 0.37 & 0.028 & 0.37 & 0.025 \\
\hline Palmitic & -0.26 & 0.125 & -0.38 & 0.022 \\
\hline Sapienic & 0.21 & 0.222 & 0.35 & 0.034 \\
\hline \multirow[t]{3}{*}{ Docosatetraenoic (n6) } & 0.37 & 0.028 & 0.28 & 0.096 \\
\hline & \multicolumn{2}{|c|}{$\begin{array}{c}\Delta \text { IL-6 } 24 \text { h } \\
(\mathrm{ng} / \mathrm{l})\end{array}$} & \multicolumn{2}{|c|}{$\begin{array}{c}\Delta \text { IL-6 } 48 \text { h } \\
(\mathrm{ng} / \mathrm{l})\end{array}$} \\
\hline & $\mathbf{r}$ & $\mathbf{p}$ & $\mathbf{r}$ & $\mathbf{p}$ \\
\hline 12-Methyltridecanoic & 0.13 & 0.455 & -0.34 & 0.049 \\
\hline 12-Methyltetradecanoic & 0.34 & 0.047 & 0.24 & 0.179 \\
\hline Sapienic & 0.38 & 0.023 & 0.14 & 0.445 \\
\hline Arachidic & 0.34 & 0.043 & 0.21 & 0.222 \\
\hline$\alpha$-Linolenic & 0.36 & 0.031 & 0.31 & 0.070 \\
\hline \multirow[t]{3}{*}{ Lignoceric } & 0.35 & 0.040 & 0.11 & 0.532 \\
\hline & \multicolumn{2}{|c|}{$\begin{array}{c}\Delta \text { SAA } 24 \text { h } \\
(\mathrm{mg} / \mathrm{l})\end{array}$} & \multicolumn{2}{|c|}{$\begin{array}{c}\Delta \mathrm{SAA} 48 \mathrm{~h} \\
(\mathrm{mg} / \mathrm{l})\end{array}$} \\
\hline & $\mathbf{r}$ & $\mathbf{p}$ & $\mathbf{r}$ & $\mathbf{p}$ \\
\hline \multirow[t]{3}{*}{ Sapienic } & 0.27 & 0.116 & 0.37 & 0.033 \\
\hline & \multicolumn{2}{|c|}{$\begin{array}{c}\Delta \text { MDA } 24 \text { h } \\
(\mu \mathrm{mol} / \mathrm{l})\end{array}$} & \multicolumn{2}{|c|}{$\begin{array}{c}\Delta \operatorname{MDA} 48 \mathrm{~h} \\
(\mu \mathrm{mol} / \mathrm{l})\end{array}$} \\
\hline & $\mathbf{r}$ & p & $\mathbf{r}$ & $\mathbf{p}$ \\
\hline Vaccenic & -0.34 & 0.044 & 0.06 & 0.727 \\
\hline$\alpha$-Linolenic & 0.25 & 0.144 & 0.33 & 0.048 \\
\hline$n-3 P U F A$ & 0.27 & 0.118 & 0.40 & 0.016 \\
\hline$n 6 / n 3$ & -0.20 & 0.250 & -0.37 & 0.028 \\
\hline
\end{tabular}

Relationships between the content of plasma fatty acids, inflammatory markers and oxidative stress were expressed as nonparametric Spearman's correlations. The $r$ value means Spearman's correlation coefficient, $p$ value is the probability of being wrong in concluding that there is a true difference between the groups. There are significant differences if $\mathrm{p} \leq 0.05$. HsCRP - high sensitive C-reactive protein, IL-6 - interleukin 6, MDA - malondialdehyde, SAA - serum amyloid A, PUFA polyunsaturated fatty acids.
Table 5. Survey of all measured fatty acids.

\begin{tabular}{|c|c|}
\hline Fatty acid & $\begin{array}{c}\text { Molecular } \\
\text { formula }\end{array}$ \\
\hline 12-Methyltridecanoic acid & 12-Me C13:0 \\
\hline Myristic acid & $\mathrm{C} 14: 0$ \\
\hline 13-Methyltetradecanoic acid & 13-Me C14:0 \\
\hline 12-Methyltetradecanoic acid & 12-Me C14:0 \\
\hline Pentadecanoic acid & $\mathrm{C} 15: 0$ \\
\hline Palmitic acid & $\mathrm{C} 16: 0$ \\
\hline Sapienic acid & C16:1 N10 \\
\hline cis-Palmitoleic acid & C16:1 N7-cis \\
\hline 14-Methylhexadecanoic acid & 14-Me C16:0 \\
\hline Heptadecanoic acid & $\mathrm{C} 17: 0$ \\
\hline Isostearic acid & 16-Me C17:0 \\
\hline Stearic acid & $\mathrm{C} 18: 0$ \\
\hline trans-Vaccenic acid & C18:1 N11-trans \\
\hline Oleic acid & C18:1 N9 \\
\hline cis-Vaccenic acid & C18:1 N7 \\
\hline Nonadecanoic acid & $\mathrm{C} 19: 0$ \\
\hline Linoleic acid & C18:2 N6 \\
\hline$\gamma$-Linolenic acid & C18:3 N6 \\
\hline Arachidic acid & $\mathrm{C} 20: 0$ \\
\hline$\alpha$-Linolenic acid & $\mathrm{C} 18: 3 \mathrm{~N} 3$ \\
\hline Stearidonic acid & $\mathrm{C} 18: 4 \mathrm{~N} 3$ \\
\hline Dihomo- $\gamma$-linolenic acid & C20:3 N6 \\
\hline Behenic acid & $\mathrm{C} 22: 0$ \\
\hline Arachidonic acid & C20:4 N6 \\
\hline Eicosatetraenoic acid (n-3) & $\mathrm{C} 20: 4 \mathrm{~N} 3$ \\
\hline Eicosapentaenoic acid (n-3) & $\mathrm{C} 20: 5 \mathrm{~N} 3$ \\
\hline Lignoceric acid & $\mathrm{C} 24: 0$ \\
\hline cis-13,16,19-Docosatrienoic acid & $\mathrm{C} 22: 3 \mathrm{~N} 3$ \\
\hline Docosatetraenoic acid (n-6) & C22:4 N6 \\
\hline Nervonic acid & C24:1 N9 \\
\hline Docosapentaenoic acid (n-6) & C22:5 N6 \\
\hline Docosapentaenoic acid (n-3) & $\mathrm{C} 22: 5 \mathrm{~N} 3$ \\
\hline Docosahexaenoic acid (n-3) & $\mathrm{C} 22: 6 \mathrm{~N} 3$ \\
\hline Cerotic acid & C26:0 \\
\hline Tetracosatetraenoic acid (n-6) & $\mathrm{C} 24: 4 \mathrm{~N} 6$ \\
\hline Tetracosapentaenoic acid (n-6) & C24:5 N6 \\
\hline Tetracosapentaenoic acid (n-3) & $\mathrm{C} 24: 5 \mathrm{~N} 3$ \\
\hline Tetracosahexaenoic acid & $\mathrm{C} 24: 6 \mathrm{~N} 3$ \\
\hline
\end{tabular}

Some authors have described a beneficial effect of n-3 PUFA, especially of eicosapentaenoic and docosahexaenoic acid, in terms of a reduction in overall mortality, mortality due to myocardial infarction and sudden death in patients with coronary heart disease 
(Bucher et al. 2002, Albert et al. 2002, Hu et al. 2002). Other studies reported that n-3 PUFA have impact on the consequences of PCI, namely that diet supplementation with n-3 PUFA results in reduction of the rate of early restenosis after coronary angioplasty (Dehmer et al. 1988). However, other authors did not observe any effect of n-3 PUFA on treatment and occurrence of restenosis after PCI (Johansen et al. 1999). We also did not find any beneficial anti-inflammatory effect of n-3 PUFA, except stearidonic acid in erythrocyte membranes, which negatively correlated with IL-6. This could have been caused by the fact that participants of our study did not use dietary supplements and our findings are based on physiological concentrations, which were extremely low.

The MDA levels correlated positively with the total amount of PUFA in erythrocyte membranes and phospholipids, which is in accordance with the fact that PUFA are the most prone to lipoperoxidation. Plasma concentrations of MDA negatively correlated with the total amount of monounsaturated fatty acids in erythrocyte membranes, which reflects the ability of MUFA to reduce oxidative stress (Perez-Martinez et al. 2010).

We have found a positive correlation between cerotic acid and an increase in SAA after $24 \mathrm{~h}$ in case of erythrocyte membranes and phospholipids. Lignoceric acid in phospholipids correlated with increase of IL- 6 in $24 \mathrm{~h}$. These fatty acids belong to the group of VLCSFA. Although VLCSFA are minor components of fatty acids in erythrocyte membranes, they play an important role in atherosclerotic disease (Matsumori et al. 2013). Plasma concentration of VLCSFA is influenced both by dietary intake and by activities of ELOV1, ELOV2, as well as by peroxisomal oxidation. Peroxisomal dysfunction could lead to higher plasma concentration of VLCSFA too (Schutgens et al. 1993).

VLCSFA are associated with a higher production of nitric oxide and proinflammatory cytokines. It was also found that higher levels of lignoceric acid in patients with acute coronary syndrome might contribute to the initiation and progression of atherosclerosis by increasing reactive oxygen species production. It has been shown that a higher level of lignoceric acid significantly correlated with higher levels of CRP and LDL particles, which participate in the atherosclerotic process. The accumulation of VLCSFA in macrophages contributed to the progress of inflammatory response in in vitro study on macrophages derived from $\mathrm{X}$-linked adrenoleukodystrophy protein deficient mice after stimulation by lipopolysaccharide (Yanagisawa et al. 2008, Matsumori et al. 2013).

In animal experiments, palmitoleic acid reduced the expression of adipokines and inflammatory markers (Cao et al. 2008, Guo et al. 2012). Despite this result, association of palmitoleic acid with higher levels of inflammatory markers and with coronary heart disease risk was reported in humans (Perreault et al. 2014, Petersson et al. 2009, Djoussé et al. 2012). The relationship between palmitoleic acid and inflammation in human probably reflects high saturated fat intake. This could be caused by the fact that MUFA arise by desaturation SFA, which stimulate inflammation by activation of TLR-4. In this case, cytotoxic and proinflammatory palmitic acid is desaturated to palmitoleic acid. Moreover, the increased content of SFA is associated with high SCD-1 activity, which may promote inflammation (Peterson et al. 2008). We found that palmitoleic acid is positively associated with higher level of SAA, but negatively associated with IL-6 in erythrocyte membranes after PCI, which indicates that the physiological effect of palmitoleic acid is not entirely clear.

Further, total SFA, and especially pentadecanoic, stearic and nonadecanoic acids have been found to be associated with increase of SAA. It corresponds to the fact that there is direct association between SFA, TNF- $\alpha$ and SAA. SFA increase the expression and secretion of TNF- $\alpha$ (Bradley et al. 2008), which subsequently increases SAA levels in serum (Popa et al. 2007). Other relationships are shown in Table 3.

Fatty acids were directly measured in erythrocyte membranes and in plasma phospholipids. As no participants were taking dietary supplements, our findings are based on the physiological concentrations. While most authors focused mainly on $n-3$ and $n-6$ PUFA, we have studied the whole spectrum of fatty acids - SFA, MUFA, BCFA and VLCSFA in relation to inflammation and oxidative stress after PCI.

The main contribution of our present study is based on the measurement of a wide range of fatty acids (38) of red blood cell membranes and plasma phospholipids. This complex approach allows elucidate in a complex way the associations between fatty acid profile and inflammation after PCI. Further, study includes evaluation of the effect of potential confounding factors, such as gender, age and diabetes.

However, a few limitations should be considered in the interpretation of our results. First, our pilot study 
contains only 36 participants, predominantly males. Second, since this is an observational cross-sectional study, no causality can be drawn.

In conclusion, erythrocyte membrane fatty acid profile affects significantly the magnitude of the inflammatory response to PCI and seems to be a better potential predictor of elevation of inflammatory markers after PCI than plasma phospholipids.

In erythrocyte membranes, individual n-6 PUFA, namely dihomo- $\gamma$-linolenic, docosatetraenoic, docosapentaenoic and linoleic acids, have been associated with elevation of IL-6. VLCSFA, namely cerotic acid, total SFA, and especially pentadecanoic, stearic and nonadecanoic acids, have been associated with increase of SAA. Palmitoleic acid in erythrocyte membranes significantly contributes to the increase of SAA after PCI but it is negatively associated with IL-6.

These findings might be of practical importance for improving clinical outcomes. Fatty acid analysis represents a promising tool for predicting patient's predisposition to inflammatory reaction after PCI. Moreover, plasma levels of specific fatty acids can be modified by a food intake or dietary supplementation. Our data indicate possibility to suppress production of proinflammatory compounds as prevention of increased inflammatory reaction and consequent restenosis after PCI.

\section{Conflict of Interest}

There is no conflict of interest.

\section{Acknowledgements}

We gratefully acknowledge the University of Pardubice for financial support of this work through grant SG FChT 05/2015 and the Regional Hospital of Pardubice, especially the Department of Cardiology and the Department of Clinical Biochemistry and Diagnostics for their cooperation.

\section{References}

ALBERT CM, CAMPOS H, STAMPFER MJ, RIDKER PM, MANSON JE, WILLETT WC, MA J: Blood levels of long-chain n-3 fatty acids and the risk of sudden death. N Engl J Med 346: 1113-1118, 2002.

BAGGA D, WANG L, FARIAS-EISNER R, GLASPY JA, REDDY ST: Differential effects of prostaglandin derived from omega-6 and omega-3 polyunsaturated fatty acids on COX-2 expression and IL-6 secretion. Proc Natl Acad Sci USA 100: 1751-1756, 2003.

BRADLEY RL, FISHER FF, MARATOS-FLIER E: Dietary fatty acids differentially regulate production of TNF-alpha and IL-10 by murine 3T3-L1 adipocytes. Obesity (Silver Spring) 16: 938-944, 2008.

BUCHER HC, HENGSTLER P, SCHINDLER C, MEIER G: N-3 polyunsaturated fatty acids in coronary heart disease: a meta-analysis of randomized controlled trials. Am J Med 112: 298-304, 2002.

BUFFON A, LIUZZO G, BIASUCCI LM, PASQUALETTI P, RAMAZZOTTI V, REBUZZI AG, CREA F, MASERI A: Preprocedural serum levels of C-reactive protein predict early complications and late restenosis after coronary angioplasty. J Am Coll Cardiol 34: 1512-1521, 1999.

CALDER PC: Long-chain fatty acids and inflammation. Proc Nutr Soc 71: 284-289, 2012.

CAO H, GERHOLD K, MAYERS JR, WIEST MM, WATKINS SM, HOTAMISLIGIL GS: Identification of a lipokine, a lipid hormone linking adipose tissue to systemic metabolism. Cell 134: 933-944, 2008.

DEHMER GJ, POMPA JJ, VAN DEN BERG EK, EICHHORN EJ, PREWITT JB, CAMPBELL WB, JENNINGS L, WILLERSON JT, SCHMITZ JM: Reduction in the rate of early restenosis after coronary angioplasty by a diet supplemented with n3 fatty acids. New Engl J Med 319: 733-740, 1988.

DJOUSSÉ L, MATTHAN NR, LICHTENSTEIN AH, GAZIANO JM: Red blood cell membrane concentration of cispalmitoleic and cis-vaccenic acids and risk of coronary heart disease. Am J Cardiol 110: 539-544, 2012.

FARZANEH-FAR R, HARRIS WS, GARG S, NA B, WHOOLEY MA: Inverse association of erythrocyte n-3 fatty acid levels with inflammatory biomarkers in patients with stable coronary artery disease: The Heart and Soul Study. Atherosclerosis 205: 538-543, 2009.

FERNANDEZ-REAL JM, BROCH M, VENDRELL J, RICART W: Insulin resistance, inflammation and serum fatty acid composition. Diabetes Care 26: 1362-1368, 2003. 
FERRUCCI L, CHERUBINI A, BANDINELLI S, BARTALI B, CORSI A, LAURETANI F, MARTIN A, ANDRESLACUEVA C, SENIN U, GURALNIK JM: Relationship of plasma polyunsaturated fatty acids to circulating inflammatory markers. J Clin Endocrinol Metab 91: 439-446, 2006.

GUO X, LI H, XU H, HALIM V, ZHANG W, WANG H, ONG KT, WOO SL, WALZEM RL, MASHEK DG, DONG H, LU F, WEI L, HUO Y, WU C: Palmitoleate induces hepatic steatosis but suppresses liver inflammatory response in mice. PLoS One 7: e39286, 2012.

HIRAFUJI M, MACHIDA T, HAMAUE N, MINAMI M: Cardiovascular protective effects of $\mathrm{n}-3$ polyunsaturated fatty acids with special emphasis on docosahexaenoic acid. J Pharmacol Sci 92: 308-316, 2003.

HU FB, BRONNER L, WILLETT WC, STAMPFER MJ, REXRODE KM, ALBERT CM, HUNTER D, MANSON JE: Fish and omega-3 fatty acid intake and risk of coronary heart disease in women. JAMA 287: 1815-1821, 2002.

IKEDA U, ITO T, SHIMADA K: Interleukin-6 and acute coronary syndrome. Clin Cardiol 24: 701-704, 2001.

INOUE T, KATO T, UCHIDA T, SAKUMA M, NAKAJIMA A, SHIBAZAKI M, IMOTO Y, SAITO M, HASHIMOTO S, HIKICHI Y, NODE K: Local release of C-reactive protein from vulnerable plaque or coronary arterial wall injured by stenting. J Am Coll Cardiol 46: 239-245, 2005.

JOHANSEN O, BREKKE M, SELJEFLOT I, ABDELNOOR M, ARNESEN H: N-3 fatty acids do not prevent restenosis after coronary angioplasty: results from the CART study. Coronary Angioplasty Restenosis Trial. J Am Coll Cardiol 33: 1619-1626, 1999.

JOHNSON MM, SWANN DD, SURETTE ME, STEGNER J, CHILTON T, FONTEH AN, CHILTON FH: Dietary supplementation with g-linolenic acid alters fatty acid content and eicosanoid production in healthy humans. J Nutr 127: 1435-1444, 1997.

KANDAR R, MUZAKOVA V, CEGAN A: Highly specific, simple and rapid method for the determination of malondialdehyde in blood using high-performance liquid chromatography. Clin Chem Lab Med 40: 1032$1035,2002$.

KERNOFF PBA, WILLIS AL, STONE KJ, DAVIES JA, MCNICOL GP: Antithrombotic potential of dihomo-gammalinolenic acid in man. Br Med J 2: 1441-1444, 1997.

KOCHIADAKIS GE, MARKETOUA ME, ARFANAKIS DA, SFIRIDAKI K, SKALIDIS EI, IGOUMENIDIS NE, HAMILOS MI, KOLYVAKI S, CHLOUVERAKIS G, KANTIDAKI E, CASTANAS E, VARDAS PE: Reduced systemic inflammatory response to implantation of sirolimus-eluting stents in patients with stable coronary artery disease. Atherosclerosis 194: 433-438, 2007.

KORNOWSKI R, HONG MK, TIO FO, BRAMWELL O, WU H, LEON MB: In-stent restenosis contributions of inflammatory responses and arterial injury to neointimal hyperplasia. $J$ Am Coll Cardiol 31: 224-230, 1998.

LASAVE LI, ABIZAID AA, PAIVA E MAIA J, DE RIBAMAR COSTA J JR, FERES F, MATTOS LA, ABIZAID AS, SIQUEIRA DA, TANAJURA LF, STAICO R, BERALDO DE ANDRADE P, BRAGA SN, SOUSA AG, SOUSA JE: Relationship between plasma C-reactive protein level and neointimal hyperplasia volume in patients with zotarolimus-eluting stents. Volumetric analysis by three-dimensional intracoronary ultrasound (in Spanish). Rev Esp Cardiol 60: 923-931, 2007.

LIUZZO G, BIASUCCI LM, GALLIMORE JR, GRILLO RL, REBUZZI AG, PEPUS MB, MASERI A: The prognostic value of C-reactive protein and serum amyloid A protein in severe unstable angina. $N$ Engl J Med 331: 417-424, 1994.

LIUZZO G, BUFFON A, BIASUCCI LM, GALLIMORE JR, CALIGIURI G, VITELLI A, ALTAMURA S, CILIBERTO G, REBUZZI AG, CREA F, PEPYS MB, MASERI A: Enhanced inflammatory response to coronary angioplasty in patients with severe unstable angina. Circulation 98: 2370-2376, 1998.

MATSUMORI R, MIYAZAKI T, SHIMADA K, KUME A, KITAMURA Y, OSHIDA K, YANAGISAWA N, KIYANAGI T, HIKI M, FUKAO K, HIROSE K, OHSAKA H, MOKUNO H, DAIDA H: High levels of very long-chain saturated fatty acid in erythrocytes correlates with atherogenic lipoprotein profiles in subjects with metabolic syndrome. Diabetes Res Clin Pract 99: 12-18, 2013.

MORENO JA, LOPÉZ-MIRANDA J, PÉREZ-MARTÍNEZ P, MARÍN C, MORENO R, GÓMEZ P, PANIAGUA JA, PÉREZ-JIMÉNEZ F: A monounsaturated fatty acid-rich diet reduces macrophage uptake of plasma oxidised low-density lipoprotein in healthy young men. Br J Nutr 100: 569-575, 2008. 
PEREZ-MARTINEZ P, GARCIA-QUINTANA JM, YUBERO-SERRANO EM, TASSET-CUEVAS I, TUNEZ I, GARCIA-RIOS A, DELGADO-LISTA J, MARIN C, PEREZ-JIMENEZ F, ROCHE HM, LOPEZ-MIRANDA $\mathrm{J}$ : Postprandial oxidative stress is modified by dietary fat: evidence from a human intervention study. Clin Sci 119: $251-261,2010$.

PERREAULT M, ROKE K, BADAWI A, NIELSEN DE, ABDELMAGID SA, EL-SOHEMY A, MA DW, MUTCH DM: Plasma levels of 14:0,16:0,16:1n-7, and 20:3n-6 are positively associated, but 18:0 and 18:2n-6 are inversely associated with markers of inflammation in young healthy adults. Lipids 49: 255-263, 2014.

PETER A, CEGAN A, WAGNER S, LEHMANN R, STEFAN N, KÖNIGSRAINER A, KÖNIGSRAINER I, HÄRING HU, SCHLEICHER E: Hepatic lipid composition and stearoyl-coenzyme A desaturase 1 mRNA expression can be estimated from plasma VLDL fatty acid ratios. Clin Chem 55: 2113-2120, 2009.

PETERSON LD, JEFFERY NM, THIES F, SANDERSON P, NEWSHOLME EA, CALDER PC: Eicosapentaenoic and docosahexaenoic acids alter rat spleen leukocyte fatty acid composition and prostaglandin E2 production but have different effects on lymphocyte functions and cell-mediated immunity. Lipids 33: 171-180, 1998.

PETERSSON H, BASU S, CEDERHOLM T, RISERUS U: Serum fatty acid composition and indices of stearoyl-CoA desaturase activity are associated with systemic inflammation: longitudinal analyses in middle-aged men. $\mathrm{Br} J$ Nutr 99: 1186-1189, 2008.

PETERSSON H, LIND L, HULTHE J, ELMGREN A, CEDERHOLM T, RISÉRUS U: Relationships between serum fatty acid composition and multiple markers of inflammation and endothelial function in an elderly population. Atherosclerosis 203: 298-303, 2009.

POPA C, NETEA MG, VAN RIEL PL, MEER VAN DER JW, STALENHOEF AF: The role of TNF-alpha in chronic inflammatory conditions, intermediary metabolism, and cardiovascular risk. J Lipid Res 48: 751-762, 2007.

RANGEL-HUERTA OD, AGUILERA CM, MESA MD, GIL A: Omega-3 long-chain polyunsaturated fatty acids supplementation on inflammatory biomakers: a systematic review of randomised clinical trials. Brit J Nutr 107: 159-170, 2012.

SCHILLINGER M, EXNER M, MLEKUSCH W, RUMPOLD H, AHMADI R, SABETI S, HAUMER M, WAGNER O, MINAR E: Vascular inflammation and percutaneous transluminal angioplasty of the femoropopliteal artery: association with aestenosis1. Radiology 225: 21-26, 2002.

SCHUTGENS RB, BOUMAN IW, NIJENHUIS AA, WANDERS RJ, FRUMAU ME: Profiles of very-long-chain fatty acids in plasma, fibroblasts, and blood cells in Zellweger syndrome, X-linked adrenoleukodystrophy, and rhizomelic chondrodysplasia punctata. Clin Chem 39: 1632-1637, 1993.

SILVA D, PAIS DE LACERDA A: High sensitivity C-reactive protein as a biomarker of risk in coronary artery disease. Rev Port Cardiol 31: 733-745, 2012.

YANAGISAWA N, SHIMADA K, MIYAZAKI T, KUME A, KITAMURA Y, SUMIYOSHI K, KIYANAGI T, IESAKI T, INOUE N, DAIDA H: Enhanced production of nitric oxide, reactive oxygen species, and proinflammatory cytokines in very long chain saturated fatty acid-accumulated macrophages. Lipids Health Dis 7 : 48, 2008.

YAQOOB P, PALA HS, CORTINA-BORJA M, NEWSHOLME EA, CALDER P: Encapsulated fish oil enriched in alpha-tocopherol alters plasma phospholipid and mononuclear cell fatty acid compositions but not mononuclear cell functions. Eur J Clin Invest 30: 260-274, 2000. 